\title{
PENGEMBANGAN KOMPETENSI PROFESIONAL GURU OLEH KEPALA SEKOLAH DASAR MELALUI PENELITIAN TINDAKAN KELAS PADA SD NEGERI U GADENG KABUPATEN PIDIE
}

\author{
Heri Fajri , Suria Setiawan \\ Dosen Fakultas Keguruan dan Ilmu Pendidikan Universitas Jabal Ghafur \\ Guru MIN 20 Pidie, Kabupaten Pidie \\ herifajriunigha@gmail.com, suria.atjeh@gmail.com.
}

\begin{abstract}
ABSTRAK
Penelitian ini bertujuan untuk mengkaji, mengamati serta menganalisis dan mendeskripsikan upaya dalam peningkatan pengembangan kompetensi profesional, salah satunya dalam melaksanakan penelitian tindakan kelas dalam upaya meningkatkan proses belajar mengajar pada SD Negeri U Gadeng Kabupaten Pidie, yang meliputi: (1) penyusunan program pengembangan kompetensi profesional guru oleh kepala sekolah pada SD Negeri U Gadeng Kabupaten Pidie; (2) proses pelaksanaan pengembangan kompetensi profesional melalui PTK; (3) kendala yang dihadapi kepala Sekolah Dasar dalam pengembangan kompetensi profesional guru. Penelitian ini menggunakan metode deskriptif kualitatif. Tehnik pengumpulan data yang digunakan adalah observasi, wawancara dan studi dokumentasi. Subjek dalam penelitian ini adalah kepala Sekolah Dasar, dan dewan guru SD Negeri U Gadeng Kabupaten Pidie. Hasil penelitian menujukan bahwa upaya kepala Sekolah Dasar dalam meningkatkan kompetensi profesional guru dapat dilihat dari: (1) adanya upaya meningkatkan dan mengembangkan kemampuan profesional baik yang dilakukan oleh kepala Sekolah Dasar maupun oleh guru sendiri, (2) adanya pemberian layanan supervisi klinis oleh kepala Sekolah Dasar, (3) meningkatkan motivasi kerja, (4) melakukan pengawasan kinerja guru, (5) pembinaan secara rutin, (6) mengadakan rapat, (7) membentuk forum KKG dan MGMP, (8) memberikan kesempatan untuk mengikuti diklat dan pelatihan serta, (9) melengkapi sarana dan prasarana yang dibutuhkan.
\end{abstract}

Kata Kunci: Pengembangan, Kompetensi Profesional, Guru.

\section{PENDAHULUAN}

Guru merupakan profesi yang dituntut untuk mampu melakukan peleburan segala kompetensi dan waktu yang dimilikinya untuk meningkatkan mutu pendidikan. Karena itu, tidak sembarang orang dapat menjadi guru. Kemampuan intelektual tidaklah dapat dipakai sebagai patokan seseorang dapat menjadi guru. Kemampuan intelektual pada dasarnya adalah penguasaan atas teori-teori ilmu pengetahuan. Sementara itu, dalam sebuah proses pembelajaran yang terjadi tidak hanya memamerkan kemampuan intelektual, tapi bagaimana kita dapat mentransfer kemampuan intelektual tersebut sehingga siswa memiliki kemampuan intelektual yang diwariskan oleh guru.
Salah satu kemampuan dasar yang harus dimiliki oleh seorang guru adalah kemampuan profesional. Kemampuan profesional adalah kemampuan yang berkaitan dengan tugas-tugas guru sebagai pembimbing, pendidik, dan pengajar. Proses pembelajaran adalah proses pemindahan atau pemantapan ilmu dari orang seorang guru kepada siswa yang menginginkan ilmu pengetahuan tersebut. Proses pembelajaran yang dilaksanakan dalam interaksi antara guru-murid bertujuan agar siswa dapat memiliki kemampuan intelektual. Guru merupakan salah satu faktor penentu keberhasilan setiap upaya peningkatan proses belajar mengajar yang bermuara pada peningkatan mutu pendidikan. 
Guru yang mampu melaksanakan pengajaran secara efektif serta efisien adalah guru yang profesional dan mampu memotivasi siswa untuk mengoptimalkan potensinya dalam kerangka pencapaian standar pendidikan yang ditetapkan.

Kompetensi profesional merupakan penguasaan materi pembelajaran secara luas dan mendalam, yang mencakup penguasaan materi kurikulum mata pelajaran di sekolah dan substansi keilmuan yang menaungi materinya, serta penguasaan terhadap struktur dan metodologi keilmuan, menguasai substansi keilmuan yang terkait dengan bidang studi memiliki indikator esensial; memahami materi ajar yang ada dalam kurikulum sekolah; memahami struktur, konsep, dan metode keilmuan yang menaungi atau koheren dengan materi ajar, menguasai struktur dan metode keilmuan memiliki indikator dan kajian kritis untuk memperdalam pengetahuan/materi bidang studi secara profesional dalam konteks global. Kompetensi Sosial merupakan kemampuan guru untuk berkomunikasi dan bergaul secara efektif dengan peserta didik, sesama pendidik, tenaga kependidikan, orang tua/peserta didik dan masyarakat sekitar, mampu berkomunikasi dan bergaul secara efektif dengan peserta didik, mampu berkomunikasi dan bergaul secara efektif dengan sesama pendidik dan tenaga kependidikan, serta mampu berkomunikasi dan bergaul secara efektif dengan orang tua/wali peserta didik dan masyarakat sekitar.

Profesionalisme merupakan sikap profesional yang berarti melakukan sesuatu sebagai pekerjaan pokok sebagai profesi dan bukan sebagai pengisi waktu luang atau sebagai hoby belaka. Seorang profesional mempunyai kebermaknaan ahli (expert) dengan pengetahuan yang dimiliki dalam melayani pekerjaannya. Tanggung jawab (responsibility) atas keputusannya baik intelektual maupun sikap, dan memiliki rasa kesejawatan menjunjung tinggi etika profesi dalam suatu organisasi yang dinamis.

Guru yang bermutu merupakan dambaan bagi pelanggan, banyak cara yang dilakukan perorangan guru atau lembaga untuk meningkatkan mutu guru, seperti melalui peningkatan jenjang akademis, workshop, penataran, peningkatan kinerja, studi banding dan sebagainya. Penambahan pengetahuan dan pengalaman dapat mengangkat mutu guru, artinya guru harus mengembangkan kapasitas dirinya untuk menjadi panutan, menjadi contoh, tempat bertanya, berdiskusi bagi pelanggannya.

Berkaitan dengan hal tersebut maka perlu melakukan pengkajian Peningkatan Kompetensi Profesional Guru melalui penelitian tindakan kelas pada SD Negeri U Gadeng Kabupaten Pidie.

\section{METODE PENELITIAN}

Penelitian ini menggunakan pendekatan kualitatif deskriptif yaitu data yang terkumpul berbentuk kata-kata atau gambaran tentang sesuatu, sehingga tidak menekankan pada angka-angka. Sebagai prosedur penelitian ini menghasilkan data yang bersifat deskriptif yaitu berupa katakata tertulis atau lisan dari orang-orang atau prilaku yang diamati dari situasi yang alamiah yang menekankan pada proses dari pada produk yang dilakukan secara intensif dan penuh hati-hati. Melalui pendekatan deskriptif kualitatif peneliti secara konfrehensif mengkaji terhadap fenomenafenomena yang terjadi dilokasi penelitian sesuai dengan fokus permasalahan yang telah ditentukan. Satori (2010:28) menyatakan bahwa: "Penelitian deskriptif merupakan metode penelitian yang bersifat naratif yang maknanya data dan fakta yang dihimpun berbentuk kata-kata atau gambar dari pada angka-angka dengan cara mengambarkan apa, mengapa dan bagaimana suatu kejadian terjadi dengan yang sebenarnya dengan cara memberikan illustrasi yang utuh untuk memberi dukungan terhadap apa yang di sajikan". Sugiyono, $(2008 ; 14)$ mengatakan metode penelitian kualitatif adalah metode penelitian berlandaskan pada filsafat postpositivesme, digunakan untuk meneliti pada kondisi obyek yang alamiah, (sebagai lawannya adalah eksperimen) dimana 
peneliti adalah sebagai instrumen kunci, pengambilan sampel sumber data dilakukan secara purposive dan snowbaal, tehnik pengumpulan dengan trianggulasi (gabungan), analisis data bersifat induktif/kualitatif, dan hasil penelitian kualitatif lebih menekankan makna daripada generalisasi.

Creswll (Satori, 2010:24), mengemukakan penelitian kualitatif adalah: Penelitian kualitatif adalah suatu proses inquiry tentang pemahaman berdasarkan pada tradisi-tradisi metodologi terpisah jelas pemeriksaan bahwa menjelajah suatu masalah sosial atau manusia,peneliti membangun suatu kompleks,gambaran holistik, meneliti kata-kata, laporan-laporan memerinci pandangan-pandangan dari penutur asli, dan melakukan studi di suatu pengaturan yang alami.

\section{HASIL PEMBAHASAN}

Program pengembangan Kompetensi Profesional guru pada SD Negeri U Gadeng Kabupaten Pidie.

Kegiatan atau upaya-upaya yang dapat dilakukan oleh kepala Sekolah Dasar untuk meningkatkan kompetensi profesionalisme guru yaitu:

\section{a. Peningkatan kemampuan profesional guru}

Secara sederhana peningkatan kemampuan profesional guru dapat diartikan sebagai upaya membantu guru yang belum matang menjadi matang, yang tidak mampu mengelola sendiri dapat mengelola sendiri, yang belum memenuhi kualifikasi menjadi memenuhi kualifikasi, yang belum terakreditasi menjadi terakreditasi, Kematangan, kemampuan mengelola sendiri, pemenuhan kualifikasi, merupakan ciri-ciri profesionalisme. Salah satu upaya atau usaha yang dapat dilakukan oleh kepala Sekolah Dasar dalam rangka peningkatan kemampuan profesional guru yang dipimpinnya, khususnya guru kelas, guru Pendidikan Agama Islam, dan guruguru lainnya, adalah supervisi pendidikan yang dilakukan secara terus menerus dan kontiu. Umumnya alat dan teknik supervisi dapat dibedakan dalam dua macam alat atau teknik. Teknik yang bersifat individual, yaitu teknik yang dilaksanakan untuk seorang guru secara individual dan teknik yang bersifat kelompok, yaitu teknik yang dilakukan untuk melayani lebih dari satu orang.

a. Tehnik individual.

Yang dimaksud dengan tehnik individual ialah supervisi yang dilakukan secara perseorangan.

b. Teknik Kelompok

Merupakan teknik yang dapat membantu guru dalam melaksanakan program supervisi yang ditujukan pada dua orang atau lebih.

1) Pertemuan orientasi bagi guru baru (orientation meeting for newteacher) .

2) Rapat guru

3) Studi kelompok antar guru

4) Lokakarya ( workshop )

5) Diskusi panel

6) Seminar

7) Perpustakaan jabatan

8) Buletin supervisi

9) Mengikuti kursus

10) Laboratorium kurikulum

11) Perjalanan sekolah untuk anggota staf (field strips)

\section{b. Supervisi klinik}

1) Pengertian supervisi klinik

Supervisi klinik pada dasarnya merupakan pembinaan performa guru dalam mengelola proses belajar-mengajar. Pelaksanaanya didesain dengan praktis serta rasional. Baik desainnya maupun pelaksanaanya dilakukan atas dasar analisis data mengenai kegiatan-kegiatan di kelas. Data dan hubungan antara guru dan supervisor merupakan dasar program, prosedur, dan strategi pembinaan perilaku mengajar guru dalam mengembangkan pembelajaran murid-murid.

2) Indikator supervisi klinik

Supervisi atau pembimbingan yang dilakukan kepala sekolah dalam pendidikan bertujuan untuk membantu pengembangan professional guru dalam pengenalan mengajar dilakukan melalui observasi sebagai dasar usaha mengubah perilaku 
mengajar guru. Jadi, Supervisi klinik merupakan suatu pembinaan performa guru dalam proses belajar-mengajar yang di desain dengan praktis dan rasional dengan cara mengobservasi guru waktu proses belajar-mengajarberlangsung.

\section{c. Peningkatan motivasi}

1) Pengertian motivasi kerja

Meneliti guru sebagai salah seorang pelaksana kegiatan pendidikan di sekolah sangat di perlukan. Tidak jarang ditemukan guru yang kurang memiliki gairah dalam melakukan tugasnya, yang berakibat kurang berhasilnya tujuan yang ingin di capai. Hal itu di sebabkan oleh berbagai faktor. Salah satunya adalah kurangnya motivasi kerja guru. Motivasi berasal dari kata motif yang dapat di artikan sebagai tenaga penggerak yang mempengaruhi kesiapan untuk memulai melakukan rangkaian kegiatan dalam suatu perilaku. Motivasi tidak dapat di amati secara langsung, tetapi dapat diinterpretasikan dari tingkah lakunya. Di samping itu, motivasi juga dapat dinilai sebagai suatu daya dorong (driving force) yang menyebabkan orang dapat berbuat sesuatu untuk mencapai tujuan. Dalam hal ini, motivasi menunjuk pada gejala yang melibatkan dorongan terhadap perbuatan tertentu.

2) Indikator motivasi kerja.

a) Dorongan untuk maju

b) Penghargaan atas tugas

c) Perhatian dari kepala Sekolah Dasar

d) MGMP dan KKG

e) Kelompok diskusi terbimbing

f) Layanan perpustakaan

\section{d. Pembinaan kinerja guru}

1) Pengertian kinerja guru.

Kinerja guru merupakan hasil kerja yang di lakukan guru terkait dengan tugas apa yang di embannya dan merupakan tanggungjawabnya. Dalam hal ini ada 5 (lima) dimensi yang berkaitan dengan kinerja guru meliputi:
a) Kualitas kerja
b) Kecepatan atau ketepatan
c) Inisiatif dalam kerja
d) Kemampuan kerja

e) Komunikasi

Pelaksanaan Program Pengembangan

Kompetensi Profesional Guru melalui Pelaksanaan PTK pada SD Negeri U Gadeng Kabupaten Pidie

Untuk mengembangkan kompetensi profesional guru agar harapan tersebut dapat terwujud tentu saja kepala sekolah sebagai top manejer memiliki kiat dan strategi tersendiri. Upaya pelaksanaan program yang dilakukan oleh kepala sekolah tentu saja tidak dalam kondisi serta merta langsung pelaksanaan begitu saja, akan tetapi pelaksanaan tersebut tentu saja membutuhkan kepada program atau perencanaan terlebih dahulu.

Kendala yang dihadapi Kepala Sekolah Dasar dalam Meningkatkan Kompetensi Profesional Guru melalui PTK pada SD Negeri U Gadeng Kabupaten Pidie

Seorang guru yang benar-benar sadar akan tugas dan tanggung jawabnya, tentulah akan selalu mawas diri, mengadakan intropeksi, selalu berusaha ingin maju agar mampu menunaikan tugasnya lebih baik, sebab itu guru dituntut untuk selalu meningkatkan kompetensinya dengan menambah pengetahuan, memperkaya pengalaman dan menambah pengetahuannya. Secara garis besar faktorfaktor yang menjadi kendala dalam pengembangan Kompetensi Profesionalisme Guru dapat di bedakan menjadi 2 (dua) kelompok, yaitu faktor internal (berasal dari guru itu sendiri) dan faktor eksternal (berasal dari luar pribadi guru)

a. Faktor internal

Faktor internal yang mempengaruhi peningkatan Kompetensi Profesionalisme sebenarnya erat kaitannya dengan syaratsyarat yang harus dimiliki oleh seorang guru. Adapun faktor-faktor yang dimaksud antara lain:

1) Latar belakang pendidikan Guru

2) Pengalaman mengajar guru

3) Tingkat kompetensi yang dimiliki guru.

b. Faktor Eksternal

Faktor eksternal yang dapat mempengaruhi peningkatan Profesionalisme guru adalah: 
1) Sarana Pendidikan

2) Pengawasan dari kepala Sekolah Dasar.

3) Kedisiplinan kerja di sekolah.

\section{KESIMPULAN}

1. Program peningkatan kompetensi profesional guru oleh kepala Sekolah Dasar dituangkan dalam beberapa kegiatan, yaitu melalui kegiatan memberikan pertolongan kepada semua guru, memberikan kesempatan untuk salaing berbagi dan tukar pendapat mengenai berbagai hal yang dialami guru, membangkitkan motivasi guru untuk terus maju dan berkembang yang dilakukan dengan cara memberikan dorongan, memberikan penghargaan atas tugas, memberikan perhatian serta memberikan pembinaan-pembinaan kinerja baik secara umum maupun khusus.

2. Pelaksanaan program pengembangan kompetensi profesional guru oleh kepala Sekolah Dasar untuk dilakukan melalui kegiatan pembinaan, rapat-rapat kedinasan, kegiatan supervisi baik supervisi kelas maupun supervisi klinis, pengembangan guru secara individu, penilaian terhadap kinerja, melibatkan dalam berbagai proses pengembangan kompetensi serta memberikan latihan atau training yang berprofesional.

3. Kendala yang sangat besar yang dihadapi kepala sekolah dalam pengembangan kompetensi profesional guru ada yang bersifat internal yang datangnya dari guru sendiri yaitu adanya sikap konservatif, kualifikasi akademik yang rendah.

\section{DAFTAR PUSTAKA}

Satori, Djam'an dan Komariah Aan, (2010). Metodologi Penelitian Kualitatif. Bandung: Afabeta.

Soud Syaifuddin Udin. (2009). Pengembangan Profesi Guru. Bandung: Alfabeta.

Sugianto, (2007). Model-model Pembelajaran Inovatif. Jakarta: Depdikbud.

Sugiyono, (2008). Metode Penelitian Pendidikan (Pendekatan Kuantitatif, Kualitatif, dan R\&D). Alfabeta: Bandung. 